\title{
PROPHYLAXIS OF VENOUS THROMBOSIS AND PULMONARY EMBOLISM IN PATIENTS WITH ACUTE TRAUMATIC SPINAL CORD LESIONS
}

\author{
By E. Rocha Casas, M.D., M. Pérez Sánchez, M.D., C. Recio Arias, M.D. and \\ J. Plaja Masip, M.D. \\ Spinal Cord Injury Unit, Rehabilitation Department, Social Security Hospital, Barcelona, \\ Spain
}

\begin{abstract}
Twenty-one patients with acute traumatic spinal cord lesions who were admitted to our Spinal Unit during 1974 have been treated with Calcium Heparin, using a dosage of 5000-7500 i.u. at I2-hourly intervals from the first days after the lesion until the use of a wheelchair, as a prophylactic measure in order to prevent venous thromboembolism. Of these 2 I patients 18 received this treatment continuously, with a resulting o per cent of venous thrombosis and o per cent of pulmonary embolisms. In the three remaining cases, treatment had to be temporarily interrupted and in one case clinical thrombo-phlebitis was clearly evident. No case of pulmonary embolism was registered. We consider this technique to be very useful in the prophylaxis of thrombo-embolic complications in this type of patient. The use of this type of prophylactic therapy, results and conclusions are discussed.
\end{abstract}

Key Words: Venous thrombosis; Prophylaxis.

\section{Introduction}

THE high incidence of deep-vein thrombosis and its complications in patients subject to stress with immobilisation and circulatory deficiency, as well as the need for prevention of the same, explains the considerable amount of medical literature available on this question: Boneu et al. (1972), Evarts and Feil (I97I), Gibbs (1957), Harris et al. (1967), Hobbs and Davies (1960), Kakkar and Jouhar (1972), Potrom et al. (1973), Salzman et al. (I97I), Sevitt (1962), Simon and Strengle (1974), Wessler (1962), Wright et al. (1952), etc. Generally, 50 per cent of pulmonary embolisms do not present clinical evidence of venous thrombosis and in 65 per cent of autopsies carried out for various reasons, evidence of thrombosis is discovered in the veins of the limbs.

In patients with acute parpalegia who are subject to a state of spinal shock, external pressures caused by bed rest and immobilisation, associated traumatisms and who are influenced by racial, climatological and metabolical factors, etc., different authors have shown an average of is per cent of thrombosis and 5-IO per cent of pulmonary embolisms which they have attempted to treat by the use of different therapeutic methods: Chahal (1974), Hachen (1974a and b), Phillips (1963), Silver (1974), Walsh and Tribe (1965), Watson (1968, 1974). The objective of this paper is to report a study of the administration of Calcium Heparin at a dosage of 5000-7500 i.u. at I2-hourly intervals as a method of antithromboembolism prophylaxis. 


\section{Material and Methods}

\section{Clinical Trial}

At the beginning of 1974 we initiated a clinical investigation in patients with acute traumatic spinal cord lesions with a view to preventing thrombo-embolic accidents. For this we used techniques based on the studies of Kakkar and others (1970, I972), using low-dose Heparin-in this case 5000-7500 i.u. of Calcium Heparin at I2-hourly intervals from the first days after the lesion until the patient was adapted to wheelchair.

We submitted $2 \mathrm{I}$ patients to this treatment-I 8 men and 3 women. Their ages ranged from $I 7$ to $8 \mathrm{I}$ years and $\mathrm{I} 2$ of them were under 30 years of age. The mechanism of lesion was in all cases traumatic, with predominance of car accidents and accidents at work. In three cases the injury was caused by misjudged dives into swimming pools and one was caused by a firearm.

The level of clinical lesion varied from a $\mathrm{C}_{4}$ to an $\mathrm{S}_{3}$. The segment distribution was 9 cervical, 7 dorsal, 4 lumbar and I sacral.

The spinal cord lesion was complete in 20 of the $2 \mathrm{I}$ cases.

Significant associated traumatic lesions were present in 5 cases (I fracture of the tibia, 2 cranial fractures, 2 rib fractures).

As regards associated illness, we found arteriosclerosis in 2 cases, spinal osteoarthritis and spondylosis deformans in 3 cases and pneumoconiosis in I case.

Radiographic studies of the osseous spinal column revealed compression fractures and compression-burst fractures in 12 cases, dislocation and fracture in 6 cases and chronic cervical spondylosis without fracture in 3 cases.

The phase of spinal shock varied from I to 45 days, with an average of 16 days. Muscular tone at the end of the treatment showed I4 patients to be in a spastic state and 7 in a flaccid state.

The period of treatment with Heparin using 5000-7500 i.u. at I2-hourly intervals varied between 37 and I2I days, with an average of 66 days.

All the patients had simultaneous treatment with different drugs and all received daily physiotherapy in the form of passive, active assisted or resisted mobilisations, according to muscular groups and level of lesion, together with respiratory physiotherapy.

Use was made of 'Egerton-Stoke Mandeville' type electric beds with postural changes every 2-3 hours during 24 hours a day.

Clinical control of the appearance of early signs of venous thrombosis was achieved by seried measurement of the perimeter of the lower limbs at thigh and calf level. We did not use the Fibrinogen-uptake test with I-I25 or I-I3I (Hobbs, 1973, Kakkar and others, 1972) as at present we only have limited experience of this technique. The control of pulmonary embolic complications was carried out by auscultation and radiographies and the control of haemorrhagic complications in the digestive and urinary systems by studies of faeces and urine.

\section{Results}

Of the 2 I patients, 18 received treatment without interruption and no case of clinical thrombo-embolism occurred (o per cent). Of the three patients whose treatment was temporarily suspended, one showed a clear case of clinical thrombophlebitis (4.7 per cent). Complications of pulmonary embolism were not present in any of the cases and haemorrhagic complications attributable to Heparin were not observed. The mortality rate of the patients for other reasons was nil. 


\section{Discussion}

Heparin (doses of 5000-7500 i.u.) was used for the following reasons:

I. The objective was to prevent venous thrombi. The development of such thrombi is affected primarily by factors of coagulation and therefore they are susceptible to modification by the use of anticoagulants, as opposed to arterial thrombi, in which platelet aggregation factors have more effect and which are therefore susceptible to modification by the use of platelet aggregation inhibitors (see Hilden et al., I96I; Sevitt, I962; Welch, I887; Emmons et al., I965; Evans et al., I968; Jorgensen et al., I967; Marcus and Zucker, I965; O'Brien, I968; Marcus, I969).

2. The properties of Heparin as regards rapidity of action, management, dosage, lack of interaction with other drugs and easy neutralisation as compared with oral anticoagulants (see Goth, I968; Lee et al., I950; Hachen, I974b; O'Reilley et al,. 1964; Stirling and Hunter, I95I; Weiner et al., I950; Weiner, 1967).

3. Conveniency of not needing to carry out seried coagulation controls (Howell's time, Thrombin time) which are not modified with the use of this technique, (Hachen, I974a; Potrom et al., 1973).

4. Thrombo-embolic and haemorrhagic complications observed previously in our Spinal Unit due either to lack of use of prophylactic anticoagulant medication or to the use of oral anticoagulants with their possible modification by drug interactions (analgesics, tranquillisers, antibiotics, etc.) which these patients also need in general in their daily evolution.

5. The good results obtained with this technique in the investigations of Kakkar (1972), Potrom (1973) in postoperative cases and confirmed in patients with spinal cord lesion by Hachen (1974a).

6. The reflex action return observed in the majority of patients once the phase of spinal shock is passed has a positive pumping effect on the blood, improving circulation and preventing stasis. Guttmann (1958) and Guttmann and Silver (I965) found the reappearance of reflex contractions of the intercostal muscles to be of help in the increase of vital capacity of the lungs.

7. We believe that the ending of this treatment when the patient advances to activities outside the bed is justified, due to the fact that greater physical activity and postural changes together with the muscular reflex activity, the increase in respiratory movements, reduction of external pressures and of the complications affecting patients in bed (Browse, 1962) permit a security margin in the prevention of thrombo-embolisms, although the possibility that these can occur does still exist.

In different spinal units favourable results have also been obtained using various types of prophylactic techniques. Hachen (1974a) in Geneva, using Io 000 i.u. of Heparin during 3 weeks followed by Sintrom until wheelchair activity was achieved, recorded a reduction in thrombosis from $2 \mathrm{I}$ to 6 per cent. Silver (1974) in Stoke Mandeville, using Phenindione during a period of 12 weeks recorded a reduction from 25 to 5 per cent. The Sheffield group (Watson, I968, 1974) using physiotherapy and continuous observation, without using anticoagulants in a prophylactic manner obtained 12 per cent. Chahal (1974) in India did not use prophylactic anticoagulants because thrombotic complications rarely occur in that country, due probably to racial, climatic and dietetic factors.

We consider the results obtained with our therapy to be very good, as the percentage of complications in the patients receiving this treatment in a continuous manner was nil. Of the three cases in which we had to temporarily withdraw 
treatment, one case of clinical thrombo-phlebitis occurred. The first of the three mentioned cases was an American male, 38 years of age, with a complete T6 lesion caused by a firearm and who suffered from bad psychological readjustment. This patient developed haematuria due to the tearing out of the catheter, in this case a permanent one, during an agitation crisis. Two days after withdrawal of Heparin treatment a clinical thrombo-phlebitis appeared, requiring curative treatment. The second case was a male patient, 25 years of age, with a C6 lesion caused by a car accident, who developed haematuria due to bladder distension. After 3 days, a difference of $3 \mathrm{~cm}$ in the perimeters of the lower limbs was observed, without signs of inflammation, and which returned rapidly to normal without requiring any treatment. The third case was a male patient of 35 years of age with a C6 lesion caused by a car accident and from whom the Heparin treatment was temporarily withdrawn due to the patient being submitted to plastic surgery to treat sacral pressure sores, without there being any thrombotic complications.

Hachen (1974a), using Heparin and later Sintrom, found that some cases of thrombosis occurred during the changeover from one to the other, recommending strict observation. Silver (1974) observed cases of thrombosis after the termination of treatment. In our case load, another patient, a 76-year-old woman with a C6 lesion, suffered a clinical thrombo-phlebitis I month after the normal treatment was finished, when she had been once more confined to bed due to urinary complications.

Of the above-mentioned patients from whom treatment was withdrawn temporarily, none developed clinical pulmonary embolism and all re-commenced the prophylactic treatment without further suspensions until wheelchair activity was achieved.

\section{Conclusions}

The continued prophylactic use of Calcium Heparin with doses of 5000-7500 i.u. at I2-hourly intervals from the first days after the lesion until wheelchair activity in patients with acute traumatic spinal cord injury has been shown to be completely favourable in a clinical trial carried out in 18 patients. Special care should be observed with patients who must be temporarily withdrawn from treatment. Out of three patients, one developed clinical thrombo-phlebitis.

Direct haemorrhagic complications are not to be expected. Complications of pulmonary embolism were not present in any of the $2 \mathrm{I}$ cases.

\section{RESUMEN}

2I pacientes afectos de lesión medular traumática aguda, admitidos en nuestra unidad de paraplégicos, durante el año I974, recibieron tratamiento con Heparina Cálcica a dosis de 5000-7500 UI cada I2 horas, desde el inicio del cuadro hasta la sedestación en silla de ruedas, como medida profiláctica para evitar el tromboembolismo venoso. De los 2 I pacientes, 18 llevaron el tratamiento de forma continuada, con resultados de $0 \%$ de trombosis venosas y $0 \%$ de embolias pulmonares clínicas. En los 3 casos restantes, hubo que suspender temporalmente el tratamiento, presentando uno de ellos un cuadro de tromboflebitis clínica. Embolia pulmonar no se registró en ningun caso. Consideramos la técnica aplicada como muy útil en la profilaxis de cuadros tromboembólicos, en este tipo de pacientes. Se discute el uso de esta pauta terapeutica, los resultados y conclusiones.

\section{RÉSUMÉ}

2I malades avec lésion traumatique aiguë de la moelle épinière, admis à notre Service de Paraplegiques pendant l'année I974, furent traités par l'héparine de calcium (dose: 5000-7500 UI) touts les 12 heures depuis les premiers jours après la lésion, jusqu'au moment 
de passer au fauteuil roulant, comme mesure préventive pour éviter des complications thrombo-emboliques veineuses. De ces 2 I sujets, I8 ont reçu un traitement continu, le résultat étant de $\% \%$ de thromboses veineuses et $\% \%$ démbolies pulmonaires. Dans les 3 autres cas, le traitement a dû être temporairement interrompu (dans un cas une thrombophlébite clinique s'est présentée). Nous n'avons observé aucun cas d'embolie pulmonaire. Nous considérons que cette technique est très utile pour la prophylaxis des complications thrombo-emboliques chez ce genre de malades. L'usage de cette thérapie prophylactique, les resultats et les conclusions sont exposées.

\section{ZUSAMMENFASSUNG}

2I Patienten mit einer schweren traumatischen Rückenmarkverletzung, die in unserem Zentrum während I974 aufgenommen wurden, haben eine Behandlung mit kalziumhaltiger Heparina erhalten, mit einer Dosis von 5000-7500 UI alle I2 Stunden vom Beginn des klinischen Bildes bis zur Üperleitung in einen Fahrstuhl, als vorbeugende Massnahme für die Vermeidung der Trombo-Embolie. Von 2I Patienten hatten 18 diese Behandlung dauernd, mit Ergebnis ०\% Trombose und ०\% Lungenembolie. In den drei restlichen Fällen musste die Behandlung zeitweise unterbrochen werden, da einer von diesen eine klare klinische Trombo-Adernentzündung zeigte. In keinem Fall ergab sich eine LungenEmbolie. Wir halten die angewandte Technik in der Profylaxis von trombo-embolischen Bildern bei Paraplegikern für sehr nützlich. Die Anwendung dieser terapeutischen Linie, die Ergebnisse und Schlussfolgerungen werden diskutiert.

\section{REFERENCES}

Boneu, B., Cathala, B., Jorda, M., Bierme, R. \& Lareng, L. (1972). Réanimation des malades à haut risque hémorragique et thromboembolique. Nouv. Presse Méd. I, 29.

BRowsE, N. (I962). Effect of bed rest on resting calf blood flow of healthy adult males. Brit. Med. F., I, $172 \mathrm{I}$.

Chahal, A. (I974). Proceedings of the Annual Scientific Meeting of the International Medical Society of Paraplegia. Discussion. Int. F. Paraplegia, 12, 202.

Emmons, P., Harrison, M., Honour, A. \& Mitchell, J. (I965). Effect of dipyridamole on human platelet behaviour. Lancet, 2, 603 .

Evans, G., Packham, M. \& Nishizawa, E. (1968). The effect of acetylsalicylic acid on platelet function. F. Exp. Med. 128, 877.

Evarts, C. \& FeIL, E. (I97I). Prevention of thromboembolic disease after elective surgery of the hip. F. Bone foint Surg. 53-A, I271.

GiBBS, N. (I957). Venous thrombosis of the lower limbs with particular reference to bedrest. Brit. F. Surg. 45, 209.

Goth, A. (1968). Medical Pharmacology. C. V. Mosby Company, New York.

Guttmann, L. (1973). Spinal Cord Injuries. Blackwell Scientific Publications, Oxford, p. 178 .

GutTMANN, L. \& Bell, D. (1958). In Suspension Therapy. Hollis M. \& Roper M. (ed.). Baillière, Tindall \& Cox, London, p. I07.

GutTMANN, L. \& Silver, J. (I965). Electromyographic studies on reflex activity of the intercostals and abdominals in cervical cord lesion. Int. F. Paraplegia, 3, I.

HACHEN, H. (I974a). Anticoagulant therapy in patients with spinal cord injury. Int. $\mathcal{F}$. Paraplegia, 12, 176.

Hachen, H. (1974b). Proceedings of the Annual Scientific Meeting of the International Medical Society of Paraplegia. Discussion. Int. F. Paraplegia, 12, 202.

HARRIS, W., SAlZman, E. \& Desanctis, R. (I967). The prevention of thromboembolic disease by prophylactic anticoagulation. f. Bone foint Surg. 49-A, 8I.

Hilden, I., IvERSEN, K. \& RAASCHOU, F. (I96I). Anticoagulants in acute myocardial infarction. Lancet, 2, 327.

HobBS, J. \& DAviES, J. (I960). Detection of venous thrombosis with I3 I-I labelled fibrinogen in the rabbit. Lancet, $2, \mathrm{I} 34$.

JORGENSEN, L., RowSELL, H. \& Hovig, T. (1967). Resolution and organization of plateletrich mural thrombi in carotid arteries of swine. Amer. F. Path. 5I, 68I.

Kakkar, V., Corrigan, T., Spindler, J., Fossard, D., Flute, P., Crelin, R., Wessler, S. \& YIN, E. (I972). Efficacy of low doses of heparin in prevention of deep-vein thrombosis after major surgery. Lancet, I5, IOI. 
PROPHYLAXIS OF VENOUS THROMBOSIS AND PULMONARY EMBOLISM I83

Kakkar, V., Howe, C., Nicolaides, A., Renney, J. \& Clarke, M. (1970). Deep-vein thrombosis of the leg. Amer. F. Surg. 120, 527.

Kakkar, V. V. \& Jouhar, A. J. (editors) (1972). Thromboembolism: Diagnosis and Treatment. Churchill Livingstone, Edinburgh, p. IOI.

Lee, C., Trevoy, L., SpInks, J. \& JAQues, L. (I950). Dicumarol labelled with C-I4. Proc. Soc. Exp. Biol. \& Med. 74, 151 .

Marcus, A. (1969). Platelet function. New Engl. F. Med. 280, I2I3.

MARCUS, A. \& ZUCKER, M. (I965). The physiology of blood platelets: Recent biochemical, morphologic and clinical research. New York: Grune (ed.).

O'BrIEN, J. (I968). Effects of salicylates on human platelets. Lancet, í, I3 April, 779.

O'Reilley, R., Aggeler, P., HoAg, M., Leong, L. \& Kropatkin, M. (I964). Hereditary transmission of exceptional resistance to coumarin anticoagulant drugs. New England F. Med. 27I, 809 .

PhILlips, R. (1963). The incidence of deep-venous thrombosis in paraplegia. Int. $\mathcal{F}$. Paraplegia, I, I 6 .

Potrom, G., SEYS, A. \& LARDENNois, B. (1973). L'Héparinothérapie sous mini-dose. Cahiers de Medicine, I4, 219.

Salzman, E., Harris, W. \& Desanctis, R. (I97I). Reduction in venous thromboembolism by agents affecting platelet function. N. England F. Med. 284, 1287.

SEVITT, S. (1962). Venous thrombosis and pulmonary embolism: their prevention by oral anticoagulants. Amer. F. Med. 33, 703 .

Silver, J. (1974). The prophylactic use of anticoagulant therapy in the prevention of pulmonary emboli in one hundred consecutive spinal injury patients. Int. F. Paraplegia, I2, 188 .

Simon, T. \& STEngle, J. (1974). Antithrombotic practice in orthopaedic surgery. Results of a survey. Clin. Orthop. 102, 181.

Stirling, M. \& Hunter, R. (I95I). Pharmacology of bis 3, 3'-(4-oxycoumarinyl) ethyl acetate (tromexan). Lancet, 2, 6I I.

WALSH, J. \& TRIBE, C. (I965). Phlebo-thrombosis and pulmonary embolism in paraplegia. Int. F. Paraplegia, 3, 209.

Watson, N. (1968). Venous thrombosis and pulmonary embolism in spinal cord injury. Int. F. Paraplegia, 6, I I3.

Watson, N. (1974). Anticoagulant therapy in the treatment of venous thrombosis and pulmonary embolism in acute spinal injury. Int. F. Paraplegia, 12, 197.

Weiner, M., Shapiro, S., AXeIrod, J., Cooper, J. \& Brodie, B. (I950). The physiological disposition of dicumarol in man. F. Pharmacol E Exp. Therap. 99, 409.

WeIner, M. (1967). The rational use of anticoagulants. Pharmacol. Physicians, I (I I), I.

Welch, W. (1887). The structure of white thrombi. Trans. Path. Soc. Philadelphia, I3, $28 \mathrm{I}$.

Wessler, S. (I962). Thrombosis in the presence of vascular stasis. Amer. F. Med. 33, 648.

WRIGHT, H., OSBORN, S. \& HAYDEN, M. (1952). Venous velocity in bedridden medical patients. Lancet, 2, 699. 